\title{
The Homecoming of Tartan: How Scotland and North America Collaborate in Shaping Tartan
}

Le retour du tartan au pays : comment l'Écosse et l'Amérique du Nord coopèrent à l'élaboration du tartan

Lauren Anne-Killian Brancaz

\section{(2) OpenEdition}

\section{Journals}

Electronic version

URL: http://journals.openedition.org/etudesecossaises/1074

DOI: 10.4000/etudesecossaises. 1074

ISSN: 1969-6337

\section{Publisher}

UGA Éditions/Université Grenoble Alpes

\section{Printed version}

Date of publication: 25 April 2016

Number of pages: $69-87$

ISBN: 978-2-84310-324-7

ISSN: 1240-1439

\section{Electronic reference}

Lauren Anne-Killian Brancaz, "The Homecoming of Tartan: How Scotland and North America

Collaborate in Shaping Tartan", Études écossaises [Online], 18 | 2016, Online since 01 January 2017,

connection on 15 March 2021. URL: http://journals.openedition.org/etudesecossaises/1074 ; DOI:

https://doi.org/10.4000/etudesecossaises.1074 


\section{The Homecoming of Tartan: How Scotland and North America Collaborate in Shaping Tartan}

In its 2010 Diaspora Engagement Plan, the Scottish Government hailed Scotland as "the first nation in Europe to publish a clear and defined plan for engaging with the Diaspora" (Scottish Government, 2010, p. 2). First applied in a Greek translation of the Old Testament to the forced exile of the Jews following the destruction of the Temple in Israel, the term diaspora has come to designate any group of people who have left their homeland, but with which they have maintained strong cultural links.

The Scots are famous for their mobility on all continents. They have travelled not just across continental Europe from France to Russia, and from Italy to Scandinavia, but also across the Americas and Australasia (Ember et al., pp. 48-56). Scottish and Irish immigrants and their descendants represent the largest ethnic communities in Canada, for instance, after the English and the French (Government of Canada, 2011, p. 1). While the latest census estimates that Scotland has a total population of over 5.2 million (National Records of Scotland, 2013, p. 2), the Scottish diaspora is believed to include between forty and sixty million people-between eight and twelve times as many people as in the homeland ("The Scottish Diaspora", 2015). In the US, over 5.8 million Americans assert that they have Scottish ancestry. This figure reaches 9.3 million if those who have Scotch-Irish ancestry are included as well (US Census Bureau, 2011, p. 50).

Over the last twenty-five years, the constitutive aspects of diaspora have been repeatedly redefined. While William Safran viewed the diaspora in 1991 as a community forced into exile that was led to undergo a long period of resettlement in the hostland (Safran, 1991, pp. 83-4), Robin Cohen argued in 1997 that migrant groups could leave their homeland voluntarily, and ultimately assimilate and integrate in their countries of adoption (Cohen, 1997, p. 6). More recently still, Rogers Brubaker has adopted an inclusive approach to diaspora which can be summed up 
by three main criteria: a) the voluntary or forced dispersion of a people over space; b) "Homeland Orientation", namely "the orientation to a real or imagined 'homeland' as an authoritative source of value, identity and loyalty"; and c) boundary maintenance, which corresponds to the conservation of a distinctive immigrant identity which differs from the culture of the host community (Brubaker, 2005, pp. 5-6).

This article offers to discuss the second main criterion identified by Rogers Brubaker- "Homeland Orientation". Professor Marjory Harper of the University of Aberdeen, one of the leading experts on Scottish emigration, has worked extensively on the mechanisms through which the Scottish diaspora has looked to Scotland for support. She has analysed two main means of contact thanks to which Scottish migrants have been able to stay in touch with their original homeland and preserve their Scottish identities-formal mechanisms such as "church, school and Scottish society", and informal mechanisms such as "place names, correspondence, family and community networks and chain migration" (Harper, 2003, p. 370).

On the one hand, Scottish migrants have remained spiritually attuned to Scotland through the establishment or the joining of a Scottish Church, and the provision of Gaelic-speaking clergymen (Harper, 2009, pp. 19-20). Through Church, Scottish migrants have found, irrespective of denomination, a source of moral advice and support to overcome the practical difficulties of the hostland. Ministers have even often served as schoolmasters and educators, as in the case of Scottish clergyman John Witherspoon, who became the president of Princeton University and who spread the concepts of the Scottish Enlightenment in the New World (Harper, 2003, p. 354). Additionally, Scottish migrants have remained attached to their homeland by founding Scottish societies, such as Burns clubs dedicated to the works of Scotland's Bard, St Andrew's societies in honour of Scotland's patron saint, and Caledonian societies. The latter two were initially set up as philanthropic associations assisting needy Scottish migrants - sometimes on the point of starvation-but these societies subsequently sponsored the preservation and development of Scottish culture overseas through Burns suppers, balls, pipe band competitions, and Scottish sports such as curling, shinty, golf, and Highland Games (Harper, 2003, pp. 359-60).

On the other hand, Scottish migrants have expressed their fondness for their homeland by giving typically Scottish place-names to towns, cities, regions, rivers, lakes, and islands across the world. Away from their nation, the Scots have recreated well-known environments through recognisable terms. The most vivid illustration of Scottish transplantation is perhaps Dunedin, the second largest city in New Zealand, named after 
Dùn Eideann, the Gaelic for Edinburgh. Its nineteenth- and early-twentiethcentury architecture is strikingly reminiscent of that found in the Scottish capital, hence its nickname Edinburgh of the South. Furthermore, the location was settled by Scots because its topography reminded them of the seafront and rugged hills of home ("Dunedin's architectural heritage", 2015; Harper, 2003, p. 326). Contact with Scotland has also been maintained through the formation of kith and kin communities, among which memories of the homeland could be shared and intermarriages encouraged. Collective solidarity among fellow Scots has helped them make a better start in their countries of adoption and overcome homesickness. Similarly, as the vehicle of impressions, experiences, successes, and failures, correspondence between migrants and the relatives they left behind has served as the record of the relationships fostered between the homeland and its diaspora (Harper, 2003, pp. 328-9).

Scottish culture has not been contained within the borders of Scotland. It has lived on in the minds of migrants who have remained attached to it, and who have regarded Scotland as "an authoritative source of value, identity and loyalty" (Brubaker, 2005, p. 5). Does it follow then that Scotland has been looking to the Scottish diaspora for guidance and support in the building of modern Scottishness? Professor Harper has identified formal and informal bridges thanks to which migrants have been able to stay in touch with their country of origin. At the same time, has Scotland come up with mechanisms ensuring that homeland and diaspora Scots have a shared understanding of what it means to be Scottish? To go back to Rogers Brubaker's analysis of diaspora, could Diaspora Orientation be added to his "Homeland Orientation" criterion in the case of the Scottish diaspora? Is there a dialogue, not just a unidirectional movement, between Scottish migrants and Scotland?

Considering the broad scope of this topic, the present article will focus on one aspect of Scottish culture which has become internationally popular - tartan. The latter will be interpreted in its widest sense. Tartan will range from its strict meaning, the colourful criss-cross woven pattern in Highland dress, to its broader acceptation in the shape of Tartan Day/ Week, a North-American event set up to celebrate Scottish culture and the relationships between Scotland, Canada, and the US. This study will demonstrate that Scotland has been mobilising its North-American diaspora in the last decade. The resilience of tartan at home and abroad - its survival, re-appraisal, and development - has partly been made possible thanks to the support of North America. 


\section{Tartan-a badge of Scottishness in Scotland and North America alike?}

In a recent study researching the role that kilts and tartans play in shaping and asserting Scottish-American identities, Ian Maitland Hume has distinguished between traditional and new Scottish Americans. The former have remained strongly attached to their homeland, or the homeland of their ancestors, by having "impeccable ancestry in that they can trace their forebears to the precise glen of origin and know exactly where their families were first established in America" (Hume, 2012, p. 84). In contrast, the latter have developed personal interpretations of what Scottish culture means to them, which depend more on affinity than ancestry (ibid., p. 85). The new Scottish Americans choose the identity they want to adopt because they find it attractive, not because they have inherited it. Hume concludes that tartan in the US is now a "potent symbol" of identity (ibid., p. 90):

Tartan provides instant linkage to a past and a probably-forgotten, possiblyimagined heritage for some, to a clear expression of Highland identity for others, to Scottish identity for many, both in Scotland and overseas, or even simply to a means to identify visibly with a collective of people with whom they share common feelings. (Ibid., p. 90)

Tartan has increasingly been tailored to the needs of diaspora Scots who have used it as a familiar beacon guiding their new lives on a different continent. Tartan has arguably become the most straightforward and outward sign of Scottishness, and/or of affinity with Scottishness in the eyes of the world.

Even though tartan is associated with Scottish culture in the minds of the North-American diaspora, it has for decades been contested in Scotland as a symbol of Scottish national identity. The North-American obsession for clans and tartans, what the diaspora "conceives as Scottish", can therefore be "excruciating for Scots" (Ray, 2010, pp. 6-7). It is believed to "sen[d] Scots into hilarity or sanctimonious diatribes" because "part of their disgust is that the diaspora still adores the Highlandist vision of Scotland which many Scots disdain” (ibid., p. 10).

The Highlandist vision in question refers to an artificial culture which in the nineteenth century fused Highland and Lowland traditions together, although the two groups initially had distinct characteristics. Whereas Highlanders in Scotland had formerly been viewed as fearsome uncivilised cattle-raiders representing a small proportion of the Scots, they came to stand for Scotland as a whole (Macaulay, 1866, p. 51). This change was to some extent popularised by Sir Walter Scott's historical 
novels, and by the pageant, known as the King's Jaunt, which the writer organised for the visit of King George IV in Edinburgh in August 1822. Scott partly revived and reimagined the Highland Dress, believed to be the traditional garment worn by Highland men in Scotland, by ordering the creation of "His Majesty's Celtic toilette" (Lockhart, 1850, p. 520), a full Highland Dress in the Royal Stuart tartan worn by George's dynastic rivals, and by having Highlanders and Lowlanders alike wear tartan. Scott contributed to merging Highland and Lowland cultures through the Highland Dress, which became a predominant symbol of Scottishness for both the military and civilians.

In the last centuries, tartan has been looked upon disapprovingly because it has been mass-produced in the fields of fashion, tourism, sports, and entertainment. Colin McArthur has especially criticised the distortions of Scotland engendered by the success of Harry Lauder in the first decades of the twentieth century, a singer and music hall comedian dressed in full Highland regalia, and by American movies Brigadoon (1954) and Braveheart (1995), which "have provoked sharp debate about how Scotland and the Scots (and in Braveheart's case, Scottish history) should be represented on screen. Some Scots have been outraged by the way they, their country and their national history have been portrayed" (McArthur, 2003, p. 1). Lauder's excessive appropriation of tartan and these two cinema productions have offered what are considered to be erroneous, regressive, and ludicrous visions of Scotland as a secluded rural country of lochs, mists, heather-covered glens, bagpipes, and tartans. They have triggered strong negative reactions from the Scots. Tartan has given rise to the derogatory term tartanry encompassing all stereotypes about Scotland, not just the excessive use of tartan. This word is not to be confused with tartanism, which designates the neutral use of tartan as a means to assert one's Scottish identity.

The idea that tartan is an artificial construct has been reinforced by a work published posthumously in 2008, but written in the mid-1970s, in which Hugh Trevor-Roper maintained that kilts and tartans were modern fabrications. According to the author, the wearing of the Highland Dress was only first recorded in the seventeenth century, not earlier. TrevorRoper argued that the kilt itself, a shorter dress known as the philibeg, was designed "twenty years after the Union" by Thomas Rawlinson, an English industrialist who specialised in furnaces and forges, to facilitate the work of the Highlanders he had hired near Inverness (Trevor-Roper, 1983, pp. 19-21). Furthermore, Trevor-Roper challenged the association of tartan patterns - or setts - with clans. He underlined the fact that only a differentiation of social status or region was initially made. Clans could only distinguish themselves from each other by wearing different 
cockades in their bonnets (ibid., p. 23). When the 1746 Dress Act made the Highland Dress illegal, the latter was turned into the uniform of the Highland regiments in the British army, and tartan patterns arguably emerged for the sole purpose of telling Highland battalions apart (ibid., p. 25). It appears that setts were not initially created to distinguish clans, and that therefore, they are not the remnants of an ancient Highland tradition.

Of all criticism of tartanry, Tom Nairn's conclusions are perhaps the most biting. In The Break-Up of Britain published in the mid-1970s, he describes the "vast tartan monster" or "this vulgar tartanry" as lying at the heart of the Kailyard, a late-nineteenth-century movement in Scottish literature regarded as overly sentimental, parochial, and nostalgic. Both tartanry and the Kailyard came into being when Scotland was undergoing an intellectual emigration emptying it of its cultural talent and replacing it with "a rootless vacuum", which explains why they have been upsetting the Scottish psyche to the point of "neurosis" (Nairn, 2003, pp. 144-57). Tartanry and the Kailyard have given birth to a form of sub-nationalism which has evolved on its own, disconnected from the high culture of the intelligentsia, to the extent of "forming a huge virtually self-contained universe of Kitsch" (ibid., p. 150). Nairn believes that tartanry has derived its enduring power from developing separately from "higher culture": "Tartanry will not wither away, if only because it possesses the force of its own vulgarity - immunity from doubt and higher culture" (ibid., p. 153).

Consequently, Scottish academics have objected to tartan because they have considered it as low culture, i.e. the culture of the masses which does not stimulate the intellect. As David Goldie argues, tartan has been vulgarised by British imperialism (Goldie, 2012, p. 237), for even Lowland regiments came to wear tartan by the middle of the nineteenth century, by the growth of mass media and the popularity of the music hall after World War One (ibid., p. 233), and by the rise of American popular culture, especially that of the cinema (ibid., pp. 234, 237). Since the 1970s, tartan has also been associated with urbanism and the working class through the Tartan Army, the name given to the fans of Scotland's national football team who wear the kilt, which seems to confirm that tartan belongs to low culture. However, looking at tartan through the lens of the intelligentsia fails to account for its enduring appeal and resilience. Tartan has been re-asserted in the contexts of international football and rugby matches over the last three decades. Likewise, the wearing of kilts and tartans at weddings, funerals, and cèilidhs in Scotland has increasingly been interpreted as a form of cultural reappropriation. 
Analysing the ways in which Scottish migrants in North America have adopted and adapted tartan can shed light on the long-lasting popularity of this badge of Scottishness. Has Scotland been looking to its North-American diaspora for inspiration?

\section{Scotland's academic re-assessment of tartan}

In compiling the collection of articles entitled From Tartan to Tartanry, Ian Brown has insisted on the present academic move away from the derogatory connotations of tartanry towards the neutral meanings of tartanism, and on the appearance of new research proving the antiquity of tartan. Hugh Cheape, for instance, has demonstrated in his study on Gaelic songs, poems, and propaganda works that tartan was firmly rooted in Gaelic culture before the Union, and that it was well in use between 1600s and the 1740s. Similarly, clan tartans appear to have been associated with families first, before being attached to regiments. Tartan was acknowledged as a badge of Scottish patriotism. Its power must have been recognised by then, otherwise British lawmakers would not have legislated against Highland Dress (Cheape, 2012, pp. 29-31). Thus, the history of tartan does not begin with the English invention of the kilt. Tartan was established in Gaelic society before the 1720s.

To back up this idea, Murray Pittock has identified key episodes of history, dating back to medieval times, which attest to the antiquity of tartan and its use before the time when Rawlinson supposedly created the kilt. These historic periods include James V's order for a "hunting suit of Highland tartan" in 1538, the involvement of Scottish Gaelic communities in the pan-British civil wars of 1638-51, the blossoming of tartan in the 1680s at the court of James, Duke of York and Albany, its adoption by the Stuart party, and its wearing for the first Jacobite Rising in 1689 (Pittock, 2012, pp. 34-6). According to Pittock, too much emphasis has been laid on Scott's 1822 pageant and on Trevor-Roper's argument that the kilt was invented by an Englishman:

Not only is it almost absurd to credit that a famous creative writer could engineer a piece of brief theatricality in one town in an age before television and thereby create a national culture; it is equally ridiculous to suppose that an English Quaker industrialist could determine the sartorial priorities of one. (Ibid., p. 34)

Pittock has shown that a tartan pageant had taken place six years before the King's Jaunt, when the Black Watch battalion had come back to Edinburgh from the Waterloo campaign. Likewise, Trevor-Roper's theory of 
invention had been introduced much earlier, in 1785 in the Edinburgh Magazine (ibid., p. 34). These examples suggest that the facts about tartan need to be disentangled.

Moreover, Pittock has defined clan tartans as "an uneasy fusion of genuine historical associations, family snobbery, marketing, and the Victorian idea of clan system, itself a means of allowing a Scottish aristocracy to differentiate itself within the British Empire without challenging it" (ibid., p. 43). Although clan patterns are to some extent modern products, Pittock has stressed their historical foundations. Pittock's analysis has been substantiated by Ian Brown's, according to which setts were already systematically associated with clans by the time of the royal visit in 1822 . Brown's research has underlined historical evidence matching up clan families and specific setts dating from the mid-eighteenth century. According to Brown, clan "identifications" were fostering "pride, or at least 'sentiment"” by then (Brown, 2012a, pp. 96-8).

Contributors to From Tartan to Tartanry have urged academics to review the history of tartan, and to understand its participatory role in shaping Scottish identity. The generations of the 1970s and 1980s have been accused of deliberately overlooking key episodes of the past to give their theories of invention more weight: "The modern denunciation and disavowal of tartan mischievously draws a veil across, and therefore effectively denies, an up-to-date view of certain vital strands in Scottish history and material culture [...]" (Cheape, 2012, p. 29). Researchers of Scottish culture have thus been requested to remain objective when dealing with the history of tartan:

A failure to seek to understand constructively the various - and fluid — natures of tartan and tartanry is a roadblock to fully exploring many aspects of contemporary Scottish culture. For the sake of progressive discussion, therefore, it is essential that sensible, measured analysis and discussion both of tartan as a historical and cultural phenomenon and of the varied nature of tartanry, positive as well as potentially negative, be undertaken without adopting reductive, restrictive and, therefore, false definitions. (Brown, 2012b, p. 10)

Re-assessing tartan consists in moving away from the pejorative connotations of tartanry to focus on the neutral meanings of tartanism, and in understanding the major part tartan has played in the shaping of identities for homeland and diaspora Scots.

Scottish culture does not spring from Scotland only. Diaspora Scots too have become "an authoritative source of value, identity and loyalty" (Brubaker, 2003, p. 5). The recent re-appraisal of tartan suggests that the concept of "Homeland Orientation" (ibid., p. 5) needs subsequently to be reviewed: 
Scottish culture in any case is not just for Scotland. [...] [W] hile Scottish culture is mother culture for the diaspora, the diaspora preserves its own versions of that Scottish culture that it holds in high regard, however they are perceived at home. [...] Scottish culture is a large, dynamic and international mansion with many houses filled by many varieties of 'authenticity' and 'truth' [...]. (Brown, 2005, pp. 139-40)

The homeland is not the sole builder of Scottishness, but to what extent is it aware of diasporic forms of Scottish culture? How has Scotland been collaborating with North America to make tartan evolve?

\section{Tartan Day-a partnership between Scotland and North America?}

Tartan Day was set up in North America in the 1980s to honour the contributions Scottish Americans have made to the formation of the US and Canada. It is held on 6 April to mark the anniversary of the Declaration of Arbroath, when Scottish diplomats wrote to Pope John XXII in 1320 to assert Scotland's longstanding independence.

Since its creation, Tartan Day has evolved into Tartan Week, a whole week devoted to the celebration of certain aspects of Scottish culture. The largest Tartan Week celebrations take place annually in New York. Their highlight is the Tartan Day Parade on Sixth Avenue. It opens with the New York mounted police holding the Scottish and American flags, followed by Scottish-American associations, clan societies, Highland and Scottish country dancing clubs, Highland Games committees, pipe bands, alumni clubs of Scotland's largest universities, and a delegation of VisitScotland, Scotland's national tourism organisation. Tartan Week in New York also involves receptions, Scottish poetry, prose, and song events, plays, concerts, and pipe band displays, exhibitions and political discussions on modern Scotland, cèilidhs, and an annual 10K run sponsored by the Scottish Government ("Tartan Week News", 2015).

The academic re-evaluation of tartan has coincided with the Scottish Government's willingness to capitalise on Scotland's relationship with its diaspora. Government officials have been striving to enhance the homeland's attractiveness on the international stage so that more people come to visit, work, and live there (Scottish Government, 2010, p. 3). Although Scotland did not create Tartan Day/Week itself, it has expressed its acceptance of the festival in four main forms: Scotland has given North America gifts for the occasion; it has advertised and sponsored this North-American event; it has sent officials to attend the celebrations; and it has set up its own form of Tartan Day/Week at home. 
These trends have been adopted by Scottish officials, including the Scottish Government and Scotland's First Minister, for over a decade now.

Scotland expressed its approval of Tartan Day/Week by lending the US the sword of William Wallace for the 2005 Tartan Week celebrations in New York. This national icon was supposed to be "held aloft and brandished" during the New York parade, but it was ultimately deemed too fragile, and exhibited instead at Grand Central Station. This antique weapon had never left the homeland before, which is evidence of the strong bonds that Scotland has forged with its North-American diaspora ("Wallace Sword on Way to Big Apple", 2005).

The Scottish Government has seized the opportunities provided by Tartan Week to showcase Scotland, and to encourage diaspora Scots as well as US tourists more generally to visit Scotland. The Official Gateway to Scotland, a website sponsored by the Scottish Government, annually publicises the events held during Tartan Week in twenty-three different States of the US. The comprehensive programme advertised by the Scottish Government is a strong incentive for all homeland Scots to visit North America, and to partake in its celebrations. It also serves to promote Scotland-based talents, such as the Universities of Edinburgh and Aberdeen, actors of the National Theatre of Scotland, the National Trust for Scotland, and the National Galleries of Scotland. Moreover, the Scottish Government has been sponsoring the annual 10K Scotland Run in Manhattan since 2004, a pre-qualifying race for the New York marathon which also offers the chance to win a three-night stay for two in Edinburgh, another occasion for Scotland to make itself better known worldwide ("Scotland Week Event Listings", 2015).

Scottish officials have attended Tartan Week in New York for almost a decade now. The Presiding Officer of the Scottish Parliament has repeatedly been appointed Grand Marshal of the New York Parade. Such was the case of Rt. Hon. George Reid in 2007 and of Rt. Hon. Alex Fergusson in 2010 ("The Origins of New York's Tartan Day", 2015). It was the turn of Rt. Hon. Tricia Marwick for the 2015 parade ("Tartan Week News", 2015). The Lord Provost of Glasgow has also held that role. Bob Winter served in 2011 ("The Origins of New York's Tartan Day", 2015). Additionally, a variety of regional and national bodies, from both the public and private sectors, have been working for Tartan Week since 2000, including the Scottish Government, the City of Edinburgh Council, and Glasgow City Council. Aberdeen City Council started participating in 2005 (Schultz, 2005, p. 4).

Tartan Week has not only been raising the social, economic, and commercial profile of Scottish cities on the international stage, but it has also enabled Scotland to improve its potential overseas in terms of "tourism, 
culture, education, business, cities, etc." (ibid., p. 4). Indeed, the homeland's presence during Tartan Week is "mainly concerned with maximising the opportunities to promote the country as a competitive location, in terms of trade, investment, tourism and leisure" (ibid., p. 5). The decision of Scottish officials to engage with the diaspora's enthusiasm for tartan, endorsed for over fifteen years now, is meant to reap long-term economic benefits for Scotland.

With the help of Tartan Week, Scotland has been fashioning the image it wants to reflect to the world. The homeland has made the most of the popularity of this North-American holiday by partaking in its core activities, and by helping develop its programme. In April 2013, for instance, representatives of the Scottish Parliament and Government seized the opportunity of the New York Parade to advertise, on a banner and parade bus, Homecoming Scotland 2014. These year-long celebrations of Scottish culture organised by VisitScotland were designed to prompt diaspora Scots to come home, to Scotland, and marked the seven hundredth anniversary of the Battle of Bannockburn ("NY Tartan Day Parade 2013/-start (h)", 2013).

Former First Minister of Scotland Alex Salmond himself visited Tartan Week in 2013 to advertise the Homecoming. Along with three Members of the Scottish Parliament, Salmond was invited as a guest of honour to the annual Tartan Day Symposium and Reception organised on Capitol Hill (Saint Andrew's Society of Washington DC, 2013, p. 5). During his stay in the US, Alex Salmond delivered three speeches explicitly referring to the Scottish independence referendum. The lectures were given in front of the Carnegie Council for Ethics in International Affairs, Princeton University, and the Brookings Institution. Salmond underlined the kinship ties existing between Scotland and the US, and emphasised the former's human and economic strengths. Salmond notably insisted on Scotland's role in shaping modern politics and economics, for instance through Adam Smith's theories on a free-market economy and human morality. These speeches were aimed at boosting Scotland's attractiveness to American investors and at enhancing its intellectual and trade relationships with the US, its "biggest trading partner, biggest foreign investor and biggest tourism market outside of the United Kingdom" (Anderson, 2013, p. 6).

Salmond expressed similar ideas during Tartan Week 2014, when he spoke in front of the Glasgow Caledonian University in New York (Salmond, 2014, pp. 1-4). He has thus been working on presenting Scotland as a power to be reckoned with, and as an ideal independent-minded partner that could contribute to "the wealth of nations", namely to a more sustainable and environmentally-friendly world. Salmond's interventions 
show that Scotland is determined to present itself as a strategic actor on the global stage which knows how to build up its image. Scotland has further asserted its acceptance of Tartan Day/Week by introducing this celebration into the homeland. The first Scottish Tartan Day initiative was launched in 2004 by the Council of Angus. Arbroath Abbey, where the Declaration of Arbroath was signed, was selected as the stage for Tartan Day in Scotland. The re-enactment of the 1320 signature was chosen as the centerpiece of the festival.

As in North America, Tartan Day in Angus has evolved into Tartan Week. Its programme has been greatly developed over the last decade. It initially included a golf tournament, a Tartan Day dinner, a clan gathering, a sword and bow competition among knights in armour, an exhibition of local food and of local arts and crafts, a traditional Scottish music session, and a cèilidh ("Welcome Home: Tartan Day Comes to Scotland", 2004). It now encompasses a wider range of cultural events, such as a short story competition, heritage exhibitions on key aspects of the shire, Highland dancing competitions, traditional Scottish singing and storytelling sessions, folk choir and piping concerts, craft workshops, talks on the Highlands, and a farmers market ("Tartan Day Scotland Festival 2013 29 March-7 April", 2013).

Since Tartan Day was initiated in Angus in 2004, other Scottish cities have introduced the concept too. Aberdeen held its first Tartan Day in 2004 ("Aberdeen gets set to don its first tartan", 2004). It kept organising an annual Tartan Day parade until 2013, but since then, Tartan Day in Aberdeen seems to have been superseded by the Kiltwalk, a 26-mile walk raising money for children's charities all over Scotland which also takes place in Edinburgh, Glasgow, and New York ("Aberdeen Kiltwalk 2015", 2015).

Tartan Day/Week in Scotland has not generated the same enthusiasm as in North America, but it reveals that a new practice set up by the diaspora can in turn be adopted by Scotland, and be followed over a decade. In the last ten years, North America has pushed Scotland to reconsider the history of tartan and to keep abreast of new developments arising within diasporic communities.

The commitment of Scottish authorities to Tartan Day/Week is consistent with the homeland's Diaspora Engagement Plan. Through the use of tartan, Scotland has sought to improve its reputation on the international stage, and to stimulate its economic growth through business, trade, and investments, so as to become a stronger nation (Scottish Government, 2010). In other words, Scottish officials have turned towards North America to help Scotland prosper. The collaborative partnership between Scotland and its North-American diaspora can be defined as 
both Homeland and Diaspora Orientation. Meanwhile, Scotland has been re-asserting its power as the cradle of Scottish culture, which suggests that it wants to be viewed as the one and only authoritative source of Scottishness.

\section{Scotland's authority over tartan}

Tartan Day/Week originated in North America, but Scotland was the first to establish structures supervising the creation and registration of tartans fifty years ago. Scotland has reinforced its authority in that field in the last twenty years, especially as tartan has been identified as a "lucrative product attracting tourists" (Scottish Parliament, 2005, p. 9).

The first structure that the homeland implemented in 1963 was called the Scottish Tartans Society (STS). It endeavoured to stimulate research on tartans, and to compile from books, tartan collections, and weavers' records a world-wide database referencing every existing tartan. This database became known as the Register of All Publicly Known Tartans (RAPKT). According to Keith Lumsden, a former researcher with the STS, the register contained an estimated 2,700 different tartans by October 2000 (Lumsden, 2000, p. 69). When the society folded at the beginning of the twenty-first century due to financial difficulties, its archives were taken over by the Scottish Tartans World Register (STWR), set up by an STS consultant called Tartan Registration Limited ("World Register", 2015).

The Scottish Tartans Authority (STA) endorsed the role of the STS. The STA was created in Scotland in October 1995 by members of the STS. The STA is still operating today. It collaborates with the leading tartan weavers and retailers of Scotland for the promotion of a deeper knowledge of tartans. The STA launched the International Tartan Index (ITI), also called the Tartan Ferret, to list and account for all historical tartans. The ITI is twice as large as the RAPKT with a total of 5,500 entries accessible to the public. The STA hails its ITI as the "world's largest and most accurate tartan database" (Scottish Tartans Authority, 2015).

In contrast, the Edinburgh-based National Archives of Scotland (NAS) released the Scottish Register of Tartans (SRT) in 2009, the year of the first Homecoming celebrating the two hundred and fiftieth anniversary of the birth of Scotland's Bard, Robert Burns. The SRT is the most comprehensive tartan database that exists to date because it encompasses the RAKPT, the ITI, and the STWR. It was conceived as the one and only official and authoritative source of all tartan patterns (Scottish Parliament, 2005, pp. 3-7). The leading weavers, designers, and kiltmakers 
of Scotland, the STA, the regional councils of Scotland, prominent Scotsmen, various Scottish universities, the National Museums of Scotland, the National Trust for Scotland, as well as other key authorities responsible for the preservation of Scotland's heritage consulted each other over the creation of the SRT. Only Scotland-based bodies were invited to that discussion, which is evidence that the homeland is determined to control the tartan industry. The consultation re-defined what tartan is, what should be done with existing tartan registers, what type of information should be recorded for each new entry in the SRT, what role the Keeper of the Register of Tartans should have, and what objectives the SRT should achieve (ibid., 2005, pp. 9-13).

According to the legislation, the SRT is an electronic database, whose purpose is "to be a repository for the preservation of tartans" and "a source of information about tartans" (National Archives, 2008, p. 1). Each tartan of the SRT is identifiable by its name, category, reference number, STA reference, STWR reference, designer, colours, and registration date, or by keywords and comments upon the tartan in question ("Guidance", 2015). The person responsible for "setting up, keeping and maintaining the Register" is the Keeper of the SRT, who also serves as the Keeper of the Records of Scotland, i.e. the archives of the nation (Scottish Register of Tartans Act 2008, 2008, pp. 1-2).

Scotland's repeated efforts to finalise a legal framework for the registration of tartans indicate that it is determined to keep ahead of new developments in the tartan industry, especially as tartan patterns are now not solely woven for Scottish clans, families, and military regiments. New tartans are woven for surnames, personal names, corporations, geographical locations, commemorative events, and artefacts, for instance. Ultimately, it is up to Scotland alone to accept or reject applications for the registration of new tartans - applications which can be submitted by anyone. Thus, the Keeper of the SRT ensures that the homeland is solely in charge of legitimising and protecting tartans.

The Lord Lyon complements the duties of the Keeper of the SRT, and adds an extra level of supervision over tartans. The Lord Lyon controls Scottish heraldry as the judge of the Edinburgh-based Court of the Lord Lyon. He has purely judicial responsibilities, while the Keeper of the SRT has the administrative role of registering tartans. As the sole King of Arms in Scotland, the Lord Lyon has imposed restrictions on the acceptance of tartans. His say is limited to the recognition of clan chiefs and clan tartans, and of certain tartans commissioned by local or governmental authorities (Scottish Parliament, 2008). Therefore, only a restricted number of tartans have been noted by the Lord Lyon. For all other tartans, applications are forwarded to the Keeper of the SRT. 
Scotland has presented itself as "hold[ing] the key to the proper authentification of tartan" (Scottish Parliament, 2005, p. 14). In so doing, the homeland has re-established itself as the centre from which modern Scottishness radiates. Through controlling tartan registration, the homeland has re-built itself over the last decades as the model which the diaspora should follow. At the same time, nevertheless, the positive re-assessment of tartan in Scotland in recent years has to some extent been made possible thanks to the innovative forms of tartan that North America has introduced. Diaspora and homeland Scots have regarded Scotland as the source of Scottish identity_ "Homeland Orientation"_-yet Scotland itself has shown itself to be open to North-American conceptions of Scottishness-Diaspora Orientation.

\section{The homecoming of tartan}

Diaspora Scots have historically looked back to Scotland as the home from which they could derive support. They have transported spiritual, educational, and associational anchors from their motherland to help them maintain their Scottish identity in a challenging new environment. Notwithstanding, the relationships between Scotland and its diaspora are not unidirectional - they are not limited to "Homeland Orientation". This case study on tartan argues that a partnership has been established between Scotland and North America. Scotland remains in charge of tartan, but North America plays a crucial part in making it evolve and become accepted as part of Scottish culture. The relationships that the homeland and its diaspora have woven with each other are similar to the vertical and horizontal stripes of tartan which combine to form a checkered pattern.

Tartan has taken larger proportions in North America than in Scotland, its place of origin. Rejected by some Scots in the 1970s and 1980s as a distorted construction of Scottishness amplified by cultural emigration, tartan is now increasingly regarded as an integral part of the Scottish past. The Scottish Government has in the last decade taken official steps to endorse tartan on an international scale, and to assert Scotland's authority over it. The homeland has harnessed the popularity of tartan to claim back the latter's ownership.

To sum up, an original form of Scottish culture has been exported overseas, and adapted to the needs of Scottish migrants and their descendants. In turn, this diasporic form of Scottish culture has been fed back into Scotland, where it has been re-assessed and further developed so as to fuse together with the cultural form that originated in the homeland. In a sense, tartan has come full circle. This can be described as the 
homecoming of tartan, to pick again upon the term chosen by VisitScotland for the year-long celebrations of Scotland and its culture inviting the diaspora to come home.

Modern Scottishness, as a culture which cannot be contained within the geographical borders of Scotland, is definable both by its "Homeland Orientation"-North-American Scots perceive the motherland as the ancestral home from which their identities are sprung - and by its Diaspora Orientation-Scotland capitalises on the success of North-American tartan innovations to improve its image on the international stage. Could tartan thus be the stepping-stone towards understanding how Scotland and its diasporas across the world cooperate with each other in building other aspects of Scottishness?

In Scotland - The Brand, David McCrone and his collaborators suggested in the 1990s that Scotland's culture and politics were clashing with each other: "It is argued that instead of a rounded thought-world in which culture and politics work together in gear, the prevalent images of Scotland are adrift from their political moorings." (McCrone et al., 1995, p. 5) A couple of decades later, this assertion has lost its power since the Scottish Government has been repeatedly involved in shaping Scottish culture through tartan. The homecoming of tartan may be regarded as a popular movement which partly draws its inspiration from North America and which is subsequently out of touch with the representational needs of modern Scotland. Nevertheless, it represents a broad trend of diaspora engagement which has been consistently followed by official authorities in Scotland for over a decade.

\section{Bibliography}

\section{Publications}

Anderson Benedict, 1998, The Spectre of Comparisons, London, Verso.

Anderson Carleton J., 2013, Scotland As a Good Global Citizen: A Discussion with First Minister Alex Salmond, Alexandria, Anderson Court Reporting. Bond Ross \& Rosie Michael, 2002, "National Identities in Post-Devolution Scotland", Scottish Affairs, no. 40, pp. 34-53.

Brown Ian, 2005, "In Exile from Ourselves?”, Études écossaises, no. 10, pp. 123-41.

_, 2012a, "Myth, Political Caricature and Monstering the Tartan", in I. Brown (ed.), From Tartan to Tartanry, Edinburgh, Edinburgh University Press, pp. 93-114.

—, 2012b, "Tartan, Tartanry and Hybridity", in I. Brown (ed.), From Tartan to Tartanry, Edinburgh, Edinburgh University Press, pp. 1-12. 
Brubaker Rogers, 2005, "The 'Diaspora' Diaspora", Ethnic and Racial Studies, vol. 28, no. 1, pp. 1-19.

Cheape Hugh, 2012, "Gheibhte Breacain Charnaid ("Scarlet Tartans Would Be Got...'): The Re-invention of Tradition", in I. Brown (ed.), From Tartan to Tartanry, Edinburgh, Edinburgh University Press, pp. 13-31.

Cohen Robin, 1997, Global Diasporas, Seattle, University of Washington Press.

DalberG-Acton John, 1963, Essays in the Liberal Interpretation of History, Chicago, McNeill.

Ember Melvin et al., 2005, Encyclopedia of Diasporas, vol. 2, New York, Springer.

Goldie David, 2012, "Don't Take the High Road: Tartanry and Its Critics", in I. Brown (ed.), From Tartan to Tartanry, Edinburgh, Edinburgh University Press, pp. 232-45.

Government of Canada, 2011, 2011 National Household Survey, Ontario, Statistics Canada.

Harper Marjory, 2003, Adventurers and Exiles, London, Profile Books Ltd.

_, 2009, "Transplanted Identities: Remembering and Reinventing Scotland across the Diaspora", in G. Morton et al. (eds), Ties of Bluid, Kin and Countrie, Guelph, Centre for Scottish Studies, pp. 19-32.

Hume Ian M., 2012, "Heritage, Tourism and Material Culture", in I. Brown (ed.), From Tartan to Tartanry, Edinburgh, Edinburgh University Press, pp. 82-92.

LockHart John G., 1850, Memoirs of the Life of Sir Walter Scott, Edinburgh, Cadell.

Lumsden Keith, 2000, "Scottish Tartans: An Indexing Challenge", The Indexer, vol. 22, no. 2, pp. 69-71.

Macaulay Thomas B., 1866, The Works of Lord Macaulay, vol. 3, London, Longmans.

McArthur Colin, 2003, Brigadoon, Braveheart and the Scots, London, Tauris.

MaCrone David et al., 1995, Scotland - The Brand, Edinburgh, Edinburgh University Press.

NAIRn Tom, 2003, The Break-Up of Britain, Edinburgh, Big Thinking.

National Archives, 2008, Scottish Register of Tartans Act 2008 (asp 7), Edinburgh, Crown Copyright.

National Records of Scotland, 2013, 2011 Census: Key Results on Population, Ethnicity, Identity, Language, Religion, Health, Housing and Accommodation in Scotland, Edinburgh, Crown Copyright.

Pittock Murray G. H., 2012, "Plaiding the Invention of Scotland", in I. Brown (ed.), From Tartan to Tartanry, Edinburgh, Edinburgh University Press, pp. 32-47. 
RaY Celeste, 2010 (May), "Ancestral Clanscapes and Transatlantic Tartaneers", paper presented to the Symposium on Return Migration, Edinburgh, Scottish Centre for Diaspora Studies.

SAFran William, 1991, "Diasporas in Modern Societies: Myths of Homeland and Return”, Diaspora, vol. 1, no. 1, pp. 83-99.

Saint Andrew's Society of Washington DC, 2013, The Whin and Whistle, vol. 6, no. 3.

Salmond Alex, 2014 (7 April), Glasgow Caledonian University Speech, Edinburgh, Grown Copyright.

Sahultz Dawn, 2005 (June), Tartan Week New Tork 2005 Feedback Report, Aberdeen, Aberdeen City Council.

The Scottish Government, 2010, Diaspora Engagement Plan, Edinburgh, Crown Copyright.

The Scottish Parliament, 2005, Consultation on the Creation of a Register of Tartan, Edinburgh, Crown Copyright.

—, 2008, 2nd Report, 2008 (Session 3) Stage 1 Report on the Scottish Register of Tartans Bill, Edinburgh, Crown Copyright.

—, 2014, Scottish Independence Referendum 2014: Results, Edinburgh, Crown Copyright.

Trevor-Roper Hugh, 1983, "The Highland Tradition of Scotland", in E. Hobsbawm \& T. Ranger (eds), The Invention of Tradition, Cambridge, Cambridge University Press, pp. 15-42.

United States Census Bureau, 2011, "Population", Statistical Abstract of the United States 2011, Washington, US Department of Commerce, pp. 1-62.

\section{Online articles}

"Aberdeen Gets Set to Don Its First Tartan", The Scotsman, July 2004. Available on <www.scotsman.com/news/aberdeen-gets-set-to-don-itstartans-1-539783> (consulted September 2015).

"Aberdeen Kiltwalk 2015", The Kiltwalk, 2015. Available on <www.the kiltwalk.co.uk/events-fundraising/past-events/29-aberdeen-kiltwalk2015> (consulted September 2015).

"Dunedin's architectural heritage", Dunedin City Council, 2015. Available on $<$ www.dunedin.govt.nz/your-council/dunedin-history/architecturalhistory $>$ (consulted January 2016).

"Guidance", Scottish Register of Tartans, 2015. Available on <www.tartan register.gov.uk/guidance.aspx $>$ (consulted September 2015).

"Minorities under International Law", United Nations Human Rights, 2015. Available on <http://www.ohchr.org/EN/Issues/Minorities/Pages/ internationallaw.aspx $>$ (consulted September 2015). 
"NY Tartan Day Parade 2013/-start (h)", You Tube, April 2013. Available on <www.youtube.com/watch?v=CuMvqfAoG9c> (consulted September 2015).

"Scotland Week Event Listings 2015", The Official Gateway to Scotland, 2015. Available on <http://www.scotland.org/whats-on/scotlandweek/scotland-week-event-listings/> (consulted September 2015).

Scottish Tartans Authority, 2015. Available on <www.tartansauthority.com/ hidden-pages/about-tartan-ferret/> (consulted September 2015).

"Tartan Day Scotland Festival 201329 March-7 April", Tartan Day Scotland, 2013. Available on <www.tartandayscotland.com/nmsruntime/ saveasdialog.asp?IID=471\&sID=739> (consulted May 2013).

"Tartan Week News", The American-Scottish Foundation, 2015. Available on <www.americanscottishfoundation.com/tartanday/tartan_news. html $>$ (consulted September 2015).

"The Origins of New York's Tartan Day", The American-Scottish Foundation, 2015. Available on <http://www.americanscottishfoundation.com/ tartanday/tartandayhistory.html> (consulted September 2015).

"The Scottish Diaspora", Scottish Tartans Authority, 2015. Available on $<$ www.tartansauthority.com/global-scots/> (consulted March 2015).

"Wallace Sword on Way to Big Apple", BBC Newes, March 2005. Available on <http://news.bbc.co.uk/1/hi/scotland/4392195.stm> (consulted September 2015).

"Welcome Home: Tartan Day Comes to Scotland", Angus Council, March 2004. Available on <www.angus.gov.uk/new/releases-archive/2004/ 2004-03-04a.htm> (consulted May 2013).

"World Register", Tartans of Scotland, 2015. Available on <www.tartans. scotland.net/world_register.cfm.htm> (consulted September 2015). 